\title{
CHANGES IN ALPINE VEGETATION OVER 50 YEARS IN THE WESTERN TATRAS (SLOVAKIA)
}

\author{
ANDREJ PALAJ, JOZEF KOLLÁR
}

Department of Ecology and Environmental Sciences, Faculty of Natural Sciences CPU in Nitra, Trieda A. Hlinku 1, 94974 Nitra, Slovak Republic; e-mail: andrej.palaj@savba.sk

Institute of Landscape Ecology, Slovak Academy of Sciences, Štefánikova 3, P.O.Box 254, 81499 Bratislava, Slovak Republic; e-mail: j.kollar@savba.sk

\begin{abstract}
Palaj A., Kollár J.: Changes in alpine vegetation over 50 years in the Western Tatras (Slovakia). Ekológia (Bratislava), Vol. 37, No. 2, p. 122-133, 2018.

This paper examines changes in alpine vegetation over 50 years in the Western Tatras part of the Western Carpathians Mountains in Slovakia. We focus on the following most widespread vegetation types: subalpine to subnival grasslands (alliance Juncion trifidi Krajina 1933), snowbed vegetation (alliance Festucion picturatae Krajina 1933) and dwarf-shrub vegetation (alliances Loiseleurio-Vaccinion Br.-Bl. in Br.-Bl. et Jenny 1926 and Vaccinion myrtilli Krajina 1933). The historical 1971-1977 sampling dataset was re-sampled in 2016-2017 and our research is based on a comparison of 40 pairs of these relevés. Herein, we studied (i) changes in species frequencies; (ii) changes in phytodiversity and site conditions using estimates of Ellenberg's eco-indices and (iii) comparison of historical and current relevés over time using the nonmetric multidimensional scaling gradient analysis (NMDS) ordination method. The frequency curves reveal differences; especially in the most frequent species at $37.5-80 \%$, which reach higher values in the current data. The higher $7.5-25 \%$ value of medium-frequent species in the historical relevés indicates progressive homogenisation of the examined vegetation. In addition, the Shannon-Wiener index of individual vegetation types revealed no significant differences in diversity or average number of species. The historical relevés included 75 species while 74 were confirmed in the current data. Statistically significant differences were determined in light factor for all three vegetation groups. This was due to the retreat of some light-demanding species. While NMDS indicated changes in Festucion and Vaccinion relevés over time, the Juncion group relevés did not follow this trend, thus confirming their high stability. The observed changes between current and historical data are attributed to changes in climate and altered land use with the cessation of grazing.
\end{abstract}

Key words: alpine grasslands, snow-bed, dwarf-shrub, changes, environmental factors.

\section{Introduction}

Alpine vegetation is typical by its mosaic-like occurrence, the high presence of endemic and relic species and its dynamics (Kliment, Valachovič, 2007). The dynamics are linked to the alpine environment (Lukniš, 1973; Midriak, 1983) and climate changes (Grabherr et al., 1995; Bahn, Körner, 2003; Pauli et al., 2012). The commonly assumed high sensitivity of alpine vegetation to climate change is largely due to invasion processes, and these are most obvious 
in azonal vegetation types such as snowbeds and at the uppermost limits of plant life (Grabherr, 2003). This paper focuses on alpine vegetation changes in the Western Tatras Mountains influenced also by land use changes that especially include the cessation of cattle and sheep grazing in the mid-1980s when this area was declared a national park (Bohuš, 1994). This is crucial for alpine vegetation changes, since the absence of grazing leads to significant accumulation of plant litter (Virtanen, 2000) and some species are vulnerable to decline or disappearance, especially those with annual life cycles and species that require canopy gaps for recruitment (Erschbamer et al., 2003).

Historical vegetation of the study area was sampled in the 1970s (Horák, 1970, 1971; Turečková, 1974; Dúbravcová, 1976; Dúbravcová et al., 1976; Pietorová, 1977). This inspired our analysis of alpine vegetation changes over the last decades. Herein, we focus on the most widespread vegetation types. These are the subalpine-to-subnival grasslands (alliance Juncion trifidi Krajina 1933), snow-bed vegetation (alliance Festucion picturatae Krajina 1933) and dwarf-shrub vegetation dominated by Vaccinium genus species.

\section{Methods}

Study area

The study area covers the $34 \mathrm{~km}^{2}$ in the Jamnícka and Račkova valley parts of the Western Tatras Mountains. This area is formed from granite, migmatite and various metamorphic rocks (Nemčok, 1994) and has Podzols soils that follow Cambisols spread at lower altitudes (Š́ly, 1964). The area also lies in the cold climate region (Plesník, 1974). The 1966-2016 temperature data were recorded at Kasper Peak meteorological station and were supplied by the Polish Institute of Meteorology and Water Management. Situated at 1,959 m a.s.l., this station is close to our study area and it established a mean annual temperature of $0.35^{\circ} \mathrm{C}$, with an average maximum of $7.81^{\circ} \mathrm{C}$ in the warmest month and an average minimum of $-7.95^{\circ} \mathrm{C}$ in the coldest month. The $1966-2016$ average monthly temperatures show a fluctuating course (Fig. 1). Long-term measurements from the Skalnaté pleso meteorological station at 1,786 $\mathrm{m}$ a.s.l. in the neighbouring High Tatras Mountains revealed a shift from a relatively warmer period in 1941-1960, through mild cooling in 1961-1990 to a warm period after 1990. The registered increase in average annual temperatures was $0.8-1.7^{\circ} \mathrm{C}$ in $1991-2012$ and $1.2^{\circ} \mathrm{C}$ between 2005 and 2012 (Hlavatá, 2013). The highest point in the study area is the Bystrá peak at 2,248 $\mathrm{m}$ a.s.l., and this is also the highest peak in the Western Tatras. The timber line at $1,400-1,500 \mathrm{~m}$ a.s.l. is affected by historical land use.

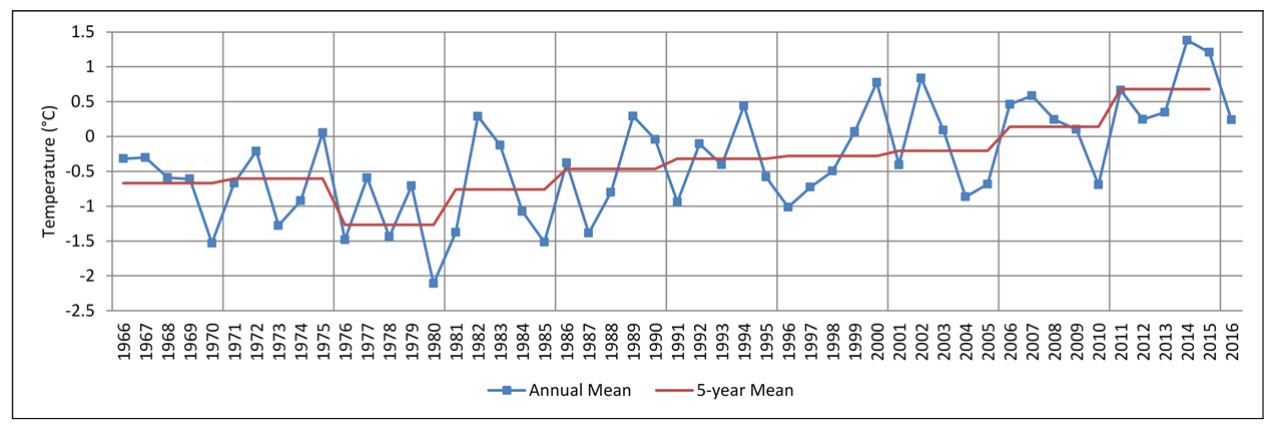

Fig. 1. Temperature change over the last 51 years (Kasper peak meteorological station). 


\section{Data sampling and analysis}

Relevés were sampled in 2016-2017. The method of generalization of long-term monitoring sites and pair comparison is used to estimate changes in plant communities (Hédl, 2005). We resampled historical relevés of 1971-1977 stored in the Central database of phytocoenological relevés (CDF) (Hegedüšová, 2007; Šibík, 2012). The methods of Zürich-Montpellier School of Phytosociology (Braun-Blanquet 1964) were used to research plant communities. The 7-figure Braun-Blanquet scale was used to estimate species coverage, and while vascular plant nomenclature was modified according to Marhold, Hindák (1998), cryptograms are not included. A major part of the phytocoenological relevés, encompassing alliances Festucion picturatae and Juncion trifidi, was published in our previous study (Palaj, Kollár, 2017). Our syntaxonomical classification of the studied vegetation agrees with Jarolímek et al. (2008). The only exception here is the dwarf shrub vegetation, which we treated as a single vegetation type under the Vaccinion group because this includes communities similar in floristic composition, physiognomy and ecology. Statistical analysis of the phytocoenological relevés is based on comparison of 40 pairs of relevés; Festucion has 14 pairs, Juncion 17 and Vaccinion 9. The analysis included the following: (i) changes in species frequencies; (ii) changes in phytodiversity and site conditions estimated by Ellenberg's eco-indices and (iii) comparison of historical and current relevés over time, using the nonmetric multidimensional scaling ordination method (NMDS). Species frequency is expressed in percentages for all three vegetation groups in both historical and current relevés. The resultant values are depicted in frequency curves for all relevés and the relative frequency change for each group is shown separately (Magurran, 2004). Shannon-Wiener (SW) and evenness indices are calculated for all historical and current relevés and the values compared in box plots. Historical and current site conditions are estimated by bioindication using Ellenberg's ecoindices (Ellenberg et al., 1992) by employing Juice software (Tichý, 2002). The box plots provide results and the paired $t$-test was performed using RStudio software (RStudio Team, 2015). Relevé (di)similarity is estimated by NMDS indirect ordination methods with the RStudio Vegan package (Oksanen et al., 2017). Finally, NMDS is performed on log-transformed data using Bray-Curtis dissimilarity matrix, and species abundances are included in all analysis.

\section{Results}

\section{Species frequency changes}

Frequency curves (Fig. 2) reveal the differences, especially in species 1-15 where the most frequent species $(37.5-80 \%)$ occur more frequently in current data and therefore have higher

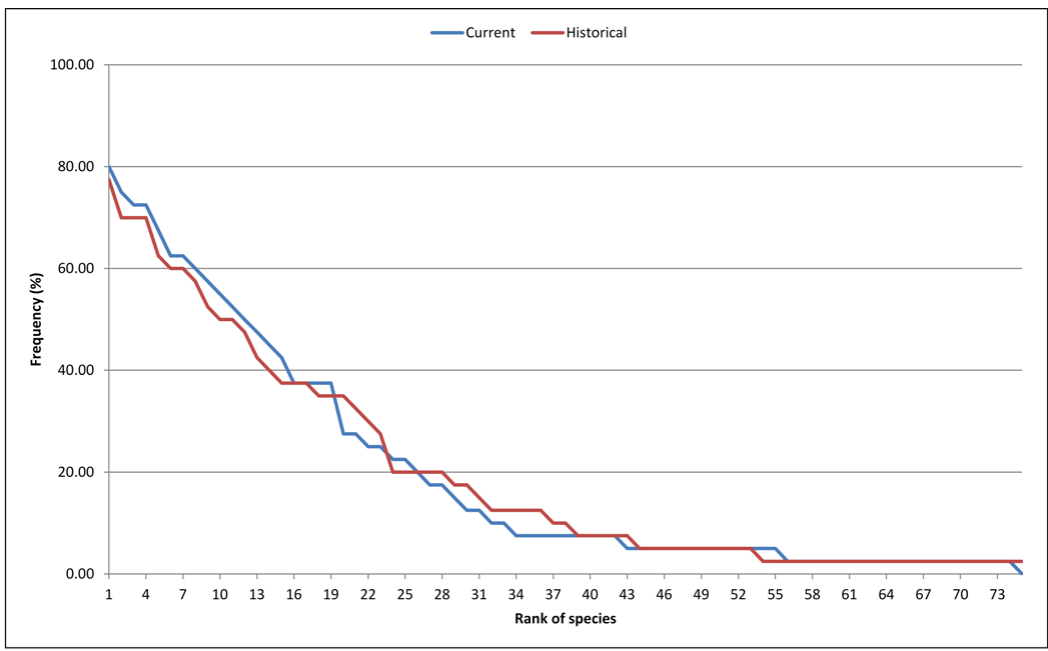

Fig. 2. Frequency curves of all species in the historical and current relevés groups. Species are ranked in descending order of frequency.

\section{4}




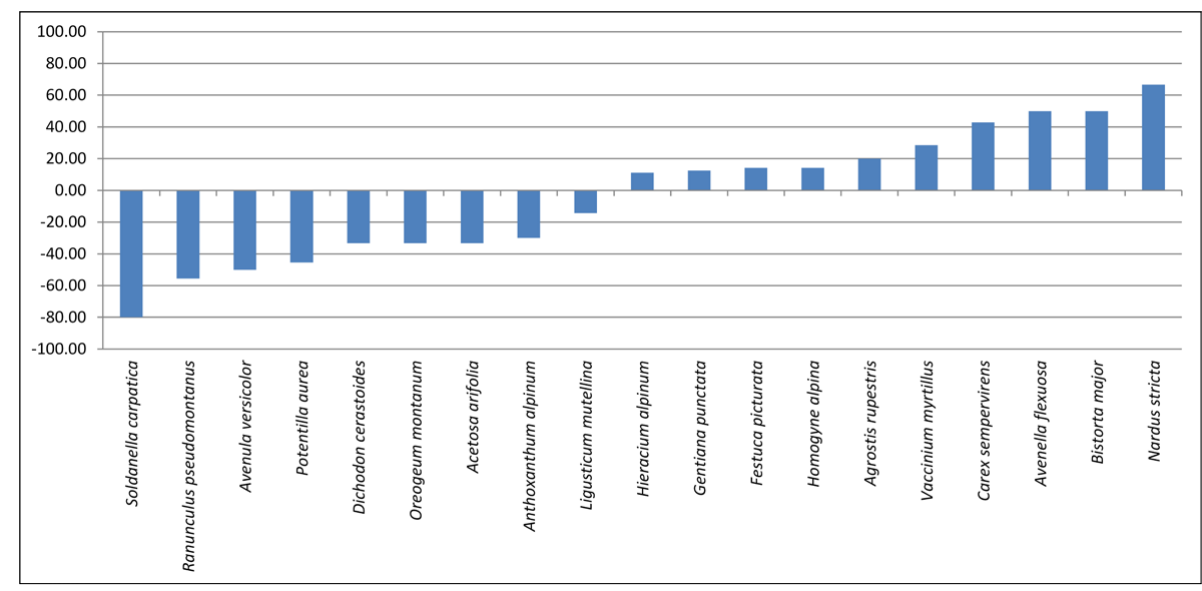

Fig. 3. Relative change in species frequency in the Festucion group.

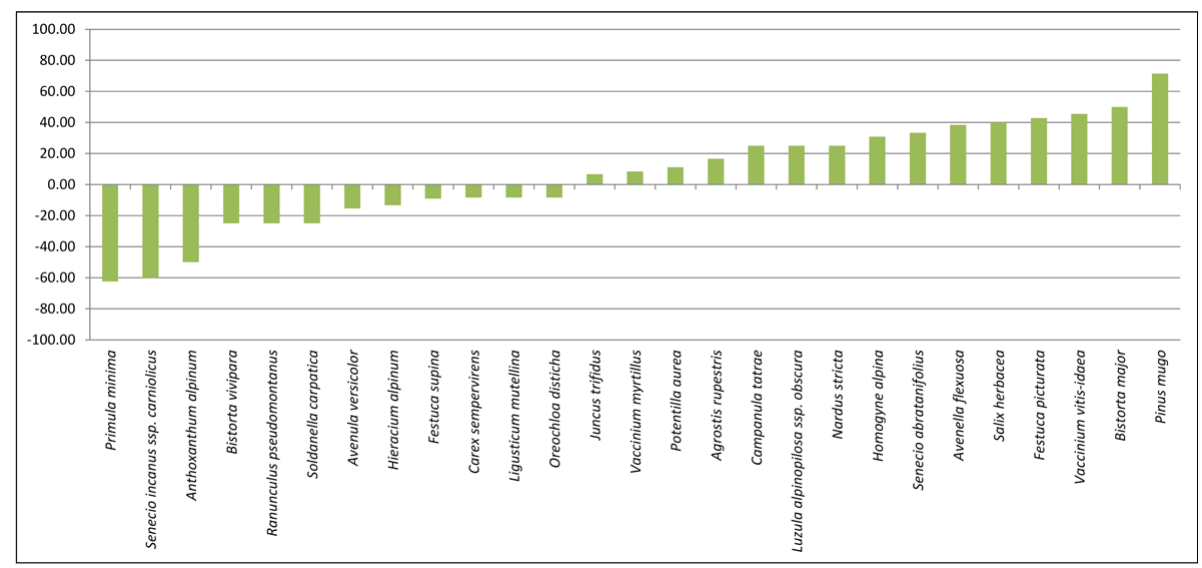

Fig. 4. Relative change of species frequencies in the Juncion group.

values. In contrast, species $19-39$ has a frequency of 7.5-25\% and higher values in the historical relevés. The historical data also included 75 species compared to 74 in our re-sampled relevés.

Relative frequency changes are shown for species with frequency exceeding $10 \%$ in the historical and current relevés. There is an obvious decrease in the frequency of current relevés in the Festucion group (Fig. 3). This is especially noted in alliance Festucion picturatae diagnostic species, including Doronicum stiriacum (-80\%), Soldanella carpatica (-80\%), Ranunculus pseudomontanus (-55.6\%) and Potentilla aurea (-45.5\%). These species are replaced by contact vegetation diagnostic species (classes Caricetea curvulae, Loiseleurio-Vaccinieta and Nardetea strictae). Important examples here are Nardus stricta $+66.7 \%$, Vaccinium myr- 


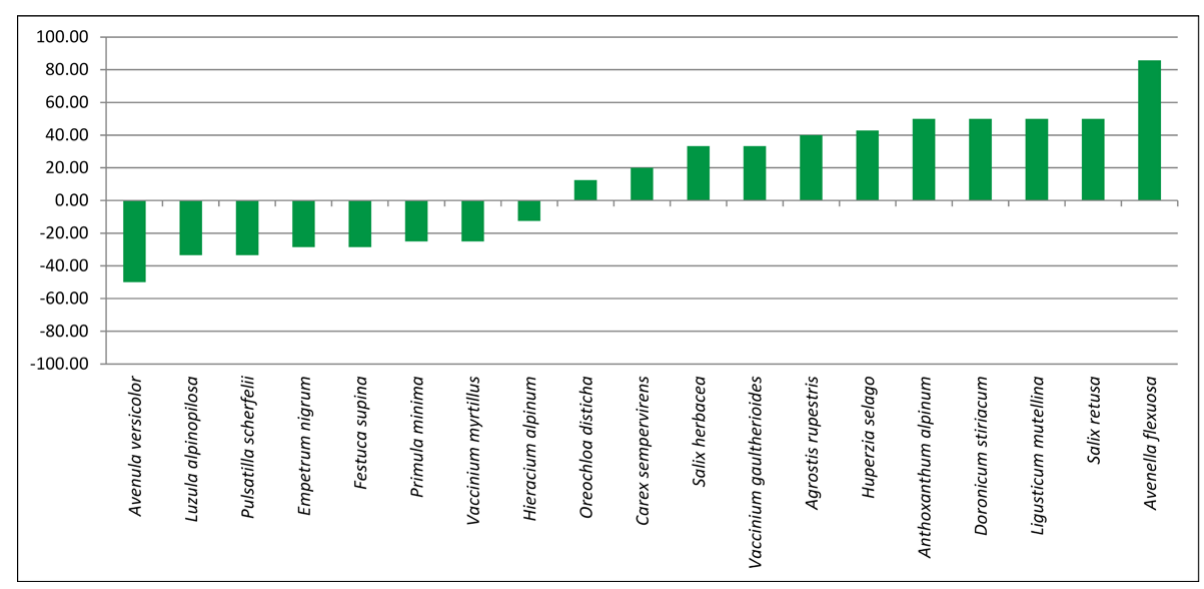

Fig. 5. Relative change in species frequency in the Vaccinion group.

tillus $+28.6 \%$, Agrostis rupestris $+20 \%$ and Hieracium alpinum $+11.1 \%$. Additional species noted in current data include Campanula serrata, Cardaminopsis neglecta, Primula minima, Juncus filiformis, Silene acaulis, Viola lutea subsp. sudetica, Achillea millefolium subsp. alpestris, Bartsia alpina, Carex nigra, Poa alpina, Pulsatilla scherfelii and Vaccinium gaultherioides. In contrast, the following species recorded in historical relevés are absent in current re-sampling: Leucanthemopsis alpina, Rhodiola rosea, Poa granitica, Campanula tatrae, Adenostyles alliariae, Cerastium fontanum, Omalotheca supina and Sedum alpestre.

Juncion vegetation group (Fig. 4) has an obvious increase in tree species, including $P i$ nus mugo (+71.4\%) and Juniperus communis (+66.7\%). Sorbus aucuparia (+100\%) was also sampled in one relevé. From neighbouring vegetation, especially from tall herb communities, Gentiana punctata (+100\%), Bistorta major (+50\%), Festuca picturata $(+42.9 \%)$, Avenella flexuosa (+38.5\%) and Luzula alpinopilosa subsp. obscura (+25\%) have also penetrated. Current data also established an obvious decrease in the frequencies of Primula minima (-62.5\%), Senecio incanus subsp. carniolicus (-60\%) and Anthoxanthum alpinum (-50\%). Additional species were recorded only in current relevés. These included typical alpine species, such as Carex bigelowii, Gentiana punctata, Carex atrata and Ligusticum mutellinoides as well as species inhabiting lower altitudes, including Calluna vulgaris, Luzula sylvatica, Sorbus aucuparia, Dryopteris filix-mas, Hieracium murorum, Luzula luzuloides and Acetosa arifolia. In contrast, the following species were recorded only in historical relevés: Euphrasia tatrae, Pseudorchis albida, Diphasiastrum alpinum, Antennaria dioica, Carex flava, C. nigra, Phleum rhaeticum, Poa alpina, Pyrola minor, Selaginella selaginoides and Tofieldia calyculata.

The Vaccinion vegetation group revealed changes in frequencies for Avenella flexuosa (+85.7\%) and Avenula versicolor (-50\%) (Fig. 5). The character and physiognomy of this vegetation is determined mainly by small shrubs, such as Empetrum nigrum, Vaccinium myrtillus and V. vitis-idea. Their current frequency, however, matches historical values. Vaccinion species recorded only in current data include Nardus stricta, Pinus mugo and Veratrum 
album subsp. lobelianum and those sampled historically account for Calamagrostis villosa, Potentilla aurea, Senecio incanus subsp. carniolicus and Soldanella carpatica.

\section{Changes in diversity and site conditions}

Differences in diversity and site conditions were analysed by paired $t$-test. The null hypothesis contended that historical and current data are not significantly different ( $\alpha=0.05)$ (Table 1 ), and significant results are presented by box plot (Fig. 6). The $t$-test results revealed no obvious differences in diversity or in the average number of species over the last 50 years. In Festucion group the average number of species decreased from 14.8 to 12.9 and the SW index decreased from 1.77 to 1.57 , but these changes were not statistically significant. In Juncion group, the SW index increased marginally from 1.96 to 2.05 and average species number from 17.02 to 17.51 . In Vaccinion group, similarly, the SW increased from 1.78 to 1.84 and the average number of species increased by 0.45 . In contrast, statistically significant differences were established in light factor
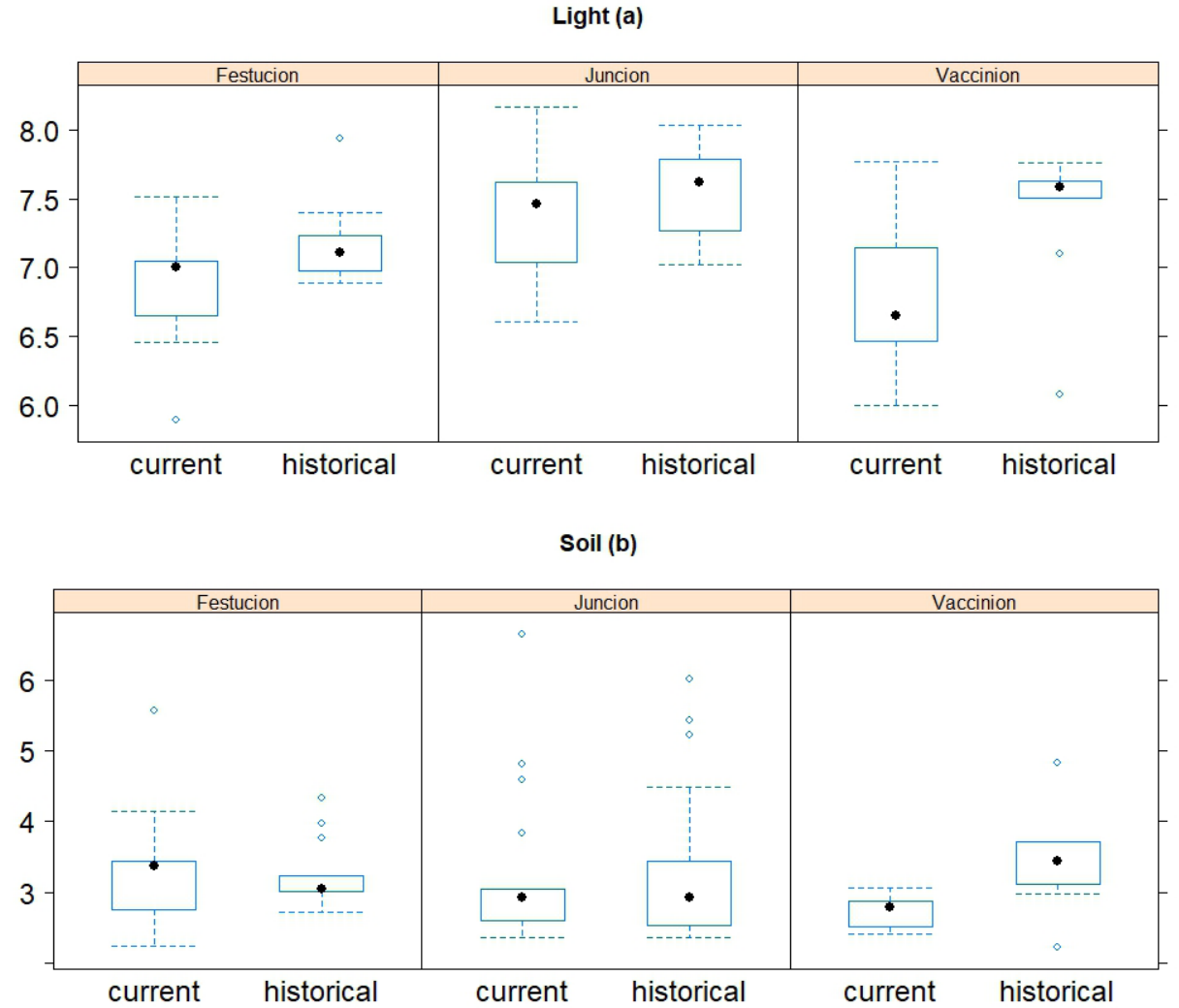

Fig. 6. Comparison of historical and contemporary site conditions estimated by Ellenberg's eco-indices (a, b). 
$\mathrm{T}$ a b l e 1. Comparison of average values for historical and contemporary site conditions estimated by Ellenberg's eco-indices and results of the Paired t-test. Abbreviations: SW - Shannon-Wiener index, E - evenness index, NOS number of species, temp - temperature, cont - continentality, mois - moisture, soil - soil reaction, nut - nutrients.

\begin{tabular}{|l|l|c|c|c|c|c|c|c|c|c|}
\hline \multicolumn{2}{|l}{} & SW & E & NOS & light & temp & cont & mois & soil & nut \\
\hline Festucion & Historical & 1.768 & 0.657 & 14.804 & 7.194 & 2.282 & 2.900 & 5.617 & 3.097 & 2.784 \\
\hline & Current & 1.568 & 0.620 & 12.899 & 6.911 & 2.511 & 3.063 & 5.595 & 3.086 & 2.838 \\
\hline & $\mathrm{t}$ & 1.238 & 0.465 & 1.738 & $2.189^{*}$ & -1.861 & -0.912 & 0.702 & -0.482 & -0.117 \\
\hline & p-value & 0.238 & 0.650 & 0.106 & 0.047 & 0.085 & 0.379 & 0.495 & 0.638 & 0.909 \\
\hline Juncion & Historical & 1.963 & 0.713 & 17.015 & 7.547 & 2.146 & 2.894 & 4.666 & 3.485 & 2.102 \\
\hline & Current & 2.050 & 0.719 & 17.515 & 7.371 & 2.237 & 2.941 & 4.671 & 3.356 & 2.196 \\
\hline & -1.048 & -0.656 & -0.550 & $2.515^{*}$ & -0.989 & -0.929 & -0.038 & 0.954 & -0.865 \\
\hline & $\mathrm{t}$ & 0.310 & 0.521 & 0.590 & 0.023 & 0.338 & 0.366 & 0.970 & 0.354 & 0.400 \\
\hline Vaccinion & Historical & 1.781 & 0.694 & 13.222 & 7.388 & 2.461 & 3.820 & 5.129 & 3.407 & 2.119 \\
\hline & Current & 1.837 & 0.711 & 13.667 & 6.821 & 2.453 & 3.768 & 4.908 & 2.733 & 2.272 \\
\hline & t -value & -0.330 & -0.397 & -0.222 & $3.234^{*}$ & 0.081 & 0.407 & 2.276 & $3.094^{*}$ & -1.311 \\
\hline & p-value & 0.750 & 0.701 & 0.830 & 0.012 & 0.937 & 0.694 & 0.052 & 0.015 & 0.226 \\
\hline
\end{tabular}

for all three groups. Light-demanding species not found in re-sampled sites included Antennaria dioica, Diphasiastrum alpinum, Pseudorchis albida, Selaginella selaginoides and Tofieldia calyculata. A significant decrease in soil reaction in the Vaccinion group is also observed.

\section{NMDS ordination diagram of historical and current relevés}

Figs 7 and 9 illustrate that NMDS ordination distinctly separated the historical and current relevés of Festucion and Vaccinion. This indicates that these vegetation types experienced a change in the studied period. However, the distribution of Juncion group relevés does not follow this pattern, and Fig. 8 highlights its stability in species composition and abundance.

\section{Discussion}

Our results on changes in the species Festucion, Juncion and Vaccinion mostly correspond with other authors' findings. With regard to climate change influences, Schei et al. (2015) report a similar pattern in species frequency changes in central Norway. This is explained by climate change, because some species' adaptation to gradual climate change is limited by competition with relatively thermophilous species migrating from lower altitudes (Abeli et al., 2012). Here, the Festucion group follows snowbed vegetation, which is the most sensitive to climate change, and similar species penetration from adjacent communities has also been observed in the Italian Rhaetian Alps (Carbognani et al., 2014). This phenomenon, and especially the increase in Vaccinion dwarf shrub abundance, is attributed to reduced snow cover duration and prolongation of the growth period (Klanderud, Birks, 2003; Cannone et al., 2007; Elmendorf et al., 2012; Grytnes et al., 2014; Vanneste et al., 2017). This increased dwarf shrub frequencies is also reported in other alpine habitats (Körner, 2003; Walker et al., 2006; De Witte, Stöcklin, 2010; Gottfried et al., 2012, Hedenås 
et al., 2016; Vanneste et al., 2017). Animal grazing is also implicated in frequency changes of species, with recognised trends due to reduction or cessation of grazing (Olofsson et al., 2001). However, the distinct increase in Nardus stricta's frequency in the Festucion group is surprising because it does not agree with other authors' findings, which have reported the retreat of this species after a reduction in grazing (Austrheim et al., 2007; Speed et al., 2014; Korzeniak, 2016).

The relatively high stability of Juncion communities over time, especially the unchanged frequency of dominant graminoids, is supported by the findings of Grabherr (2003) and Dúbravcová and Jarolímek (2007). Here, the increased frequency of reptile chamaephytes (Calluna vulgaris, Vaccinium myrtillus, V. vitis-idaea) appears linked to land use and climate changes. The most significant changes were found in dwarf pine stands (Pinus mugo) at lower altitudes. These are considered less typical in species composition (Zeidler et al., 2010). Neighbouring dwarf pines also affect both spatiotemporal snow distribution and airflow (Liston et al., 2002) and these altered site conditions gradually change the structure of communities that require strong, permanent winds because of their intolerance to deep snow. Expansion of dwarf pines and other tree species (Juniperus communis, Sorbus aucuparia) causes retreat of light-demanding species such as Primula minima, Senecio incanus subsp. carniolicus and Avenula versicolor. Similar trends have been reported in the Hrubý Jeseník Mts. alpine zone (Zeidler et al., 2010). The edge-

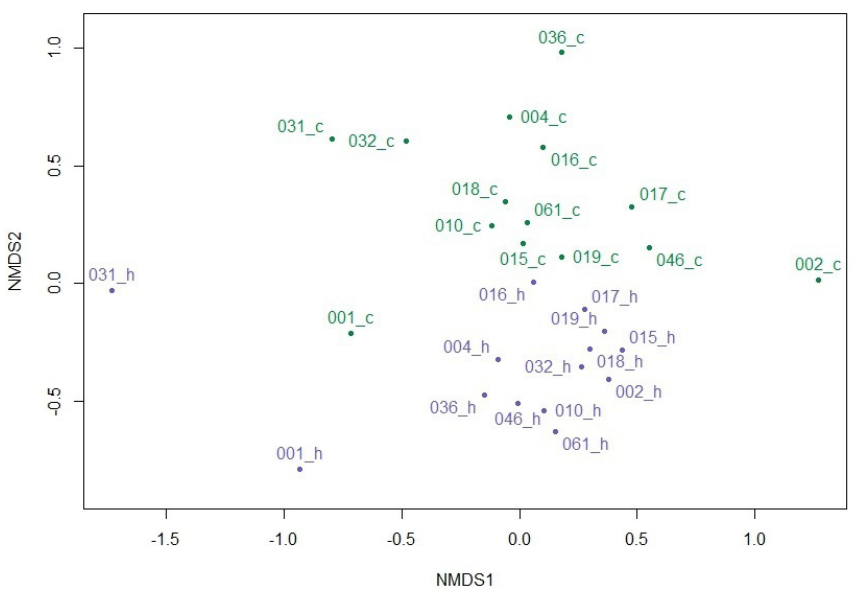

Fig. 7. NMDS ordination diagram $(\mathrm{k}=3)$ showing the distribution of current and historical relevés of Festucion vegetation group. Suffix _h indicates historical relevés.

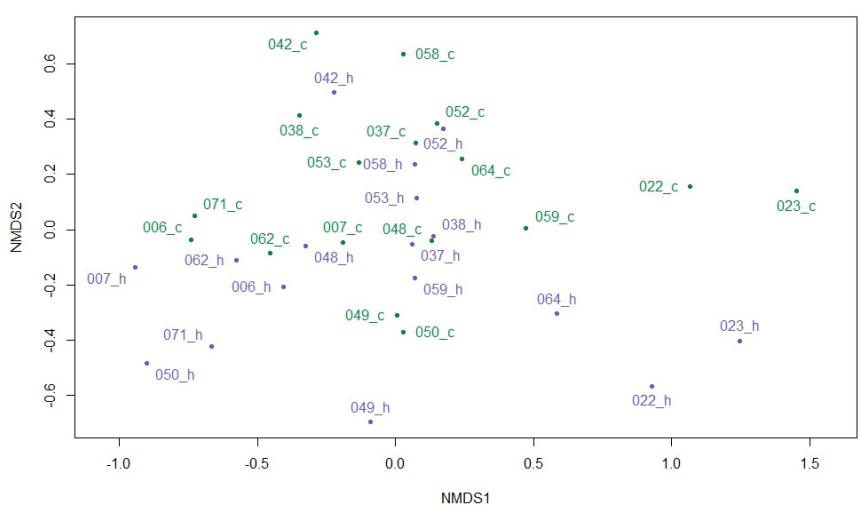

Fig. 8. NMDS ordination diagram $(\mathrm{k}=3)$ showing the distribution of current and historical relevés of Juncion vegetation group. Suffix _h indicates historical relevés. 


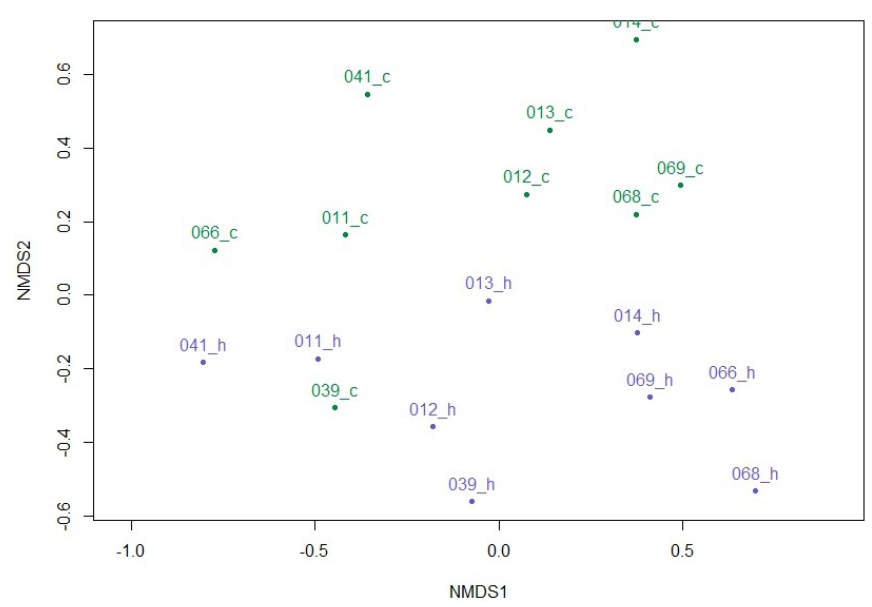

Fig. 9. NMDS ordination diagram $(\mathrm{k}=3)$ showing the distribution of current and historical relevés of Vaccinion vegetation group. Suffix _h indicates historical relevés. effect of dwarf pine stands also establishes conditions for nutrient-demanding species from lower altitudes including Dryopteris filix-mas, Hieracium murorum and Luzula luzuloides (Soukopová et al., 2001).

While there was no change in Vaccinion group frequencies of small shrubs that determine stand physiognomy, the results indicate competition with increased $V$. gaultherioides and decreased $V$. myrtillus. Although similar results were reported by Gerdol et al. (2000) these were not con-

firmed in later research (Brancaleoni, Gerdol, 2006). Vaccinium vitis-idea is the most sensitive reptile chamaephyte noted in climate change studies. While Kudo and Suzuki (2003) reported that it is suppressed by other small shrubs, especially V. myrtillus, we did not confirm this suppression. Acidophilous small shrub communities are considered very stable at high altitudes, but their succession can lead to dwarf pine stands (Šibík et al., 2007). This trend is indicated in our results by increased Pinus mugo frequency recorded in three relevés at lower altitudes, and together with strongly competitive species such as Avenella flexuosa and Veratrum album subsp. lobelianum, it has led to significant changes in Ellenberg indicator value for light. Increased soil reaction is caused by increased frequency of Agrostis rupestris, Avenella flexuosa and Huperzia selago and abundance at lower altitudes. Šmarda (1963) adds that soil reaction can also be changed by increased frequency of Nardus stricta, which strongly acidifies soils.

Although our studied vegetation groups include communities with different ecological demands, all three show significant changes in light conditions. The noted decrease in light-demanding species and those preferring nutrient-poor soils is related to grazing cessation (WitkowskaŽuk, Ciurzycki, 2000; Johansson et al., 2011; Korzeniak, 2016).

While our results show that changes in community structures are not generally reflected in diversity loss, exceptions here are a decrease in the light-demanding species such as Antennaria dioica, Diphasiastrum alpinum, Pseudorchis albida, Selaginella selaginoides and Tofieldia calyculata. Species competition is also evident in this study. Decrease in small species population density is often caused by competitive increase in taller neighbouring species (Tilman, 1988). Grazing cessation is also accompanied by promotion of expansion of phanerophytes, reptile chamaephytes and tall grasses. Our example of such a good competitor is Avenella flexuosa with its distinct $53.1 \%$ increase in frequency, and this is supported by similar trend in alpine pastures in the Polish part of the Tatras Mountains (Korzeniak, 2016) and in former alpine pastures in southern Norway 
(Austrheim et al., 2007; Speed et al., 2014). The recovery and competitive ability of this species is largely due to cessation of previous vast cattle grazing. Further consequence of grazing cessation is seen in the accumulation of biomass, which has no consumers (Šmarda, 1963), and subsequent decomposition is limited by the harsh alpine climate (Gavazov, 2010). This also suppresses the terophyte and geophyte reproduction confirmed in this research by the decreases in the following species: Euphrasia tatrae (-100\%), Veronica alpina (-100\%), Carex nigra (-50\%) and Doronicum stiriacum (-37.5\%).

\section{Acknowledgements}

This study was supported by Slovak Agency for Science (VEGA) grant 2/0132/18. We are grateful to Raymond Marshall for improving English.

\section{References}

Abeli, T., Rossi, G., Gentili, R., Mondoni, A. \& Cristofanelli P. (2012). Response of alpine plant flower production to temperature and snow cover fluctuation at the species range boundary. Plant Ecol., 213, 1-13. DOI: 10.1007/s11258011-0001-5.

Austrheim, G., Mysterud, A., Hassel,, K., Evju, M. \& Okland R.H. (2007). Interactions between sheep, rodents, graminoids, and bryophytes in an oceanic alpine ecosystem of low productivity. Ecoscience, 14, 178-187. DOI: 10.2980/1195-6860(2007)14[178:IBSRGA]2.0.CO;2.

Bahn, M. \& Körner Ch. (2003). Recent increases in summit flora caused by warming in the Alps. In L. Nagy, G. Grabherr, Ch. Körner \& D.B.A. Thompson (Eds.), Alpine biodiversity in Europe (pp. 437-442). Berlin: Springer-Verlag.

Bohuš, I. (1994). Agriculture (in Slovak). In I. Vološčuk (Ed.), Tatras National Park. Biosphere Reserve (pp. 256-260). Martin: GRADUS.

Brancaleoni, L. \& Gerdol R. (2006). Recovery of subalpine dwarf shrub heath after neighbour removal and fertilization. Plant Ecol., 183, 227-235. DOI: 10.1007/s11258-005-9020-4.

Braun-Blanquet, J. (1964). Pflanzensoziologie. Grundzüge der Vegetationskunde. Wien \& New York: Springer Verlag.

Cannone, N., Sgorbati, S. \& Guglielmin M. (2007). Unexpected impacts of climate change on alpine vegetation. Frontiers in Ecology and the Environment, 5, 360-364. DOI: 10.1890/1540-9295(2007)5[360:UIOCCO]2.0.CO;2.

Carbognani, M., Tomaselli, M. \& Patraglia A. (2014). Current vegetation changes in an alpine late snowbed community in the south-eastern Alps (N-Italy). Alpine Botany, 124, 105-113. DOI: 10.1007/s00035-014-0135-x.

De Witte, L.C. \& Stöcklin J. (2010). Longevity of clonal plants: why it matters and how to measure it. Ann. Bot. (Lond)., 106, 859-870. DOI: 10.1093/aob/mcq191.

Dúbravcová, Z. (1976). Subalpine and alpine vegetation in Kamenistá and Gáborova dolina valleys (Western Tatras) (in Slovak). Msc, PhD thesis, Faculty of Natural Sciences, Comenius University, Bratislava.

Dúbravcová, Z., Foltínová, J., Paclová, L. \& Turečková J. (1976). Vegetation of subalpine and alpine zone in Western Tatras (in Slovak). Report (msc.), Faculty of Natural Sciences, Comenius University, Bratislava.

Dúbravcová, Z. \& Jarolímek I. (2007). Caricetea curvulae (in Slovak). In J. Kliment \& M. Valachovič (Eds.), Plant communities of Slovakia. 4. Alpine vegetation (pp. 319-340). Bratislava: Veda, vydavatel'stvo SAV.

Ellenberg, H., Weber, H.E., Düll, R., Wirth, W., Werner, W. \& Paulissen D. (1992). Zeigerwerte von Pflanzen in Mitteleuropa. Scripta Geobotanica, 18, 1-258.

Elmendorf, S.C., Henry, G.H.R., Hollister, R.D., Björk, R.G., Bjorkman, A.D., Callaghan, T.V., Collier, L.S., Cooper, E.J., Cornelissen, J.H.C., Day, T.A., Fosaa, A.M., Gould, W.A., Grétarsdóttir, J., Harte, J., Luise, H., Hik, D. S., Hofgaard, A., Jarrad, F., Jónsdóttir, I.S., Keuper, F., Klanderud, K., Klein, J.A., Koh, S., Kudo, G., Lang, S.I., Loewen, V., May, J.L., Mercado, J., Michelsen, A., Molau, U., Myers-Smith, I.H., Oberbauer, S.F., Pieper, S., Post, E., Rixen, Ch., Robinson, C.H., Schmidt, N.M., Shaver, G.R., Stenström, A., Tolvanen, A., Totland, Ø., Troxler, T., Wahren, C.-H., Webber, P.J., Welker, J.M. \& Wookey P.A. (2012). Global assessment of experimental climate warming on tundra vegetation: heterogeneity over space and time. Ecol. Lett., 15, 164-175. DOI: 10.1111/j.1461-0248.2011.01716.x.

Erschbamer, B., Virtanen, R. \& Nagy L. (2003). The impacts of vertebrate grazers on vegetation in European High Mountains. In L. Nagy, G. Grabherr, Ch. Körner \& D.B.A. Thompson (Eds.), Alpine biodiversity in Europe (pp. 377-396). Berlin: Springer-Verlag. 
Gavazov, K.S. (2010). Dynamics of alpine plant litter decomposition in a changing climate. Plant Soil, 337, 19-32. DOI: 10.1007/s11104-010-0477-0.

Gerdol, R., Brancaleoni, L., Menghini, M. \& Marchesini P. (2000). Response of dwarf shrubs to neighbour removal and nutrient addition and their influence on community structure in a subalpine heath. J. Ecol., 88, 1-12. DOI: 10.1046/j.1365-2745.2000.00445.x.

Gottfried, M., Pauli, H., Futschik, A., Akhalkatsi, M., Barančok, P., Alonso, J.L.B., Coldea, G., Dick, J., Erschbamer, B., Calzado, M.R.F., Kazakis, G., Krajči, J., Larsson, P., Mallaun, M., Michelsen, O., Moiseev, O., Moiseev, P., Molau, U., Merzouki, A., Nagy, L., Nakhutsrishvili, G., Pedersen, B., Pelino, G., Mihai, P., Rossi, G., Stanisci, A., Theurillat, J.-P., Tomaselli, M., Villar, L., Vittoz, P., Vogiatzakis, I. \& Grabherr G. (2012). Continent-wide response of mountain vegetation to climate change. Nature Climate Change, 2, 111-115. DOI: 10.1038/nclimate1329.

Grabherr, G., Gottfried, M., Gruber, A. \& Pauli H. (1995). Patterns and current changes in Alpine Plant Diversity. In F.S. Chapin III \& C. Körner (Eds.), Arctic and alpine biodiversity: patterns, causes and ecosystem consequences (pp. 167-181). Ecological Studies, 113. Berlin: Springer.

Grabherr, G. (2003). Alpine vegetation dynamics and climate change - a synthesis of long-term studies and observations. In L. Nagy, G. Grabherr, Ch. Körner \& D.B.A. Thompson (Eds.), Alpine biodiversity in Europe (pp. 399-410). Berlin: Springer-Verlag.

Grytnes, J.-A., Kapfer, J., Jurasinski, G., Birks, H.H., Henriksen, H., Klanderud, K., Odland, A., Ohlson, M., Wipf, S. \& Birks H.J.B. (2014). Identifying the driving factors behind observed elevational range shifts on European mountains. Glob. Ecol. Biogeogr., 23, 876-884. DOI: 10.1111/geb.12170.

Hedenås, H., Christensen, P. \& Svensson J. (2016). Changes in vegetation cover and composition in the Swedish mountain region. Environ. Monit. Assess., 188, 452. DOI: 10.1007/s10661-016-5457-2.

Hegedüšová, K. (2007). Central database of phytosociological samples (CDF) in Slovakia (in Slovak). Bulletin Slovenskej Botanickej Spoločnosti, 29, 124-129.

Hédl, R. (2005). Monitoring of vegetation changes. In D. Vačkář (Ed.), Indicators of biodiversity change (pp. 171 -194). Praha: Academia.

Hlavatá, H. (2013). Air temperature (in Slovak). In S. Bičárová (Ed.), Skalnaté pleso SAS Observatory. 70 years of meteorological measurement (pp. 29-33). Stará Lesná: Geofyzikálny ústav SAV.

Horák, J. (1970). Geobiocoenosis of timber line. Part I. - Western Tatras, Jamnická and Račková dolina valleys (in Czech). Brno: University of Agriculture.

Horák, J. (1971). Westliche Tatra - Geobiozönosen der oberen Wald und Krummholzgrenze. Praha: ČSAV.

Jarolímek, I., Šibík, J., Hegedüšová, K., Janišová, M., Kliment, J., Kučera, P., Májeková, J., Michálková, D., Sadloňová, J., Šibíková, J., Škodová, I., Uhlířová, J., Ujházy, K., Ujházyová, M., Valachovič, M. \& Zaliberová M. (2008). A list of vegetation units of Slovakia. In I. Jarolímek \& J. Šibík (Eds.), Diagnostic, constant and dominant species of higher vegetation units of Slovakia (pp. 295-329). Bratislava: Veda, vydavatel'stvo SAV.

Johansson, V.A., Cousins, S.A.O. \& Eriksson O. (2011). Remnant populations and plant functional traits in abandoned semi-natural grasslands. Folia Geobot., 46, 165-179. DOI: 10.1007/s12224-010-9071-8.

Klanderud, K. \& Birks H. (2003). Recent increases in species richness and shifts in altitudinal distributions of Norwegian mountain plants. Holocene, 13, 1-6. DOI: 10.1191/0959683603hl589ft.

Kliment, J. \& Valachovič M. (Eds.) (2007). Plant communities of Slovakia. 4. Alpine vegetation (in Slovak). Bratislava: Veda, vydavatel'stvo SAV.

Korzeniak, J. (2016). Mountain Nardus stricta grasslands as a relic of past farming - the effects of grazing abandonment in relation to elevation and spatial scale. Folia Geobot., 51, 93-113. DOI: 10.1007/s12224-016-9246-z.

Körner, C. (2003). Alpine plant life. Functional plant ecology of high mountain ecosystems. Berlin: Springer Verlag.

Kudo, G. \& Suzuki S. (2003). Warming effects on growth, production, and vegetation structure of alpine shrubs: a five-year experiment in northern Japan. Oecologia, 135, 280-287. DOI: 10.1007/s00442-003-1179-6.

Liston, G., McFadden, J.P., Sturm, M. \& Pielke R.A. (2002). Modelled changes in arctic tundra snow, energy and moisture fluxes due to increased shrubs. Global Change Biology, 8, 17-32. DOI: 10.1046/j.1354-1013.2001.00416.x.

Lukniš, M. (1973). Relief of Tatras Mts. and their vicinity (in Slovak). Bratislava: Veda, vydavatelstvo SAV.

Magguran, A.E. (2004). Measuring biological biodiversity. Oxford: Backwell Science.

Marhold, K. \& Hindák F. (Eds.) (1998). Chcecklist of non-vascular and vascular plants of Slovakia. Bratislava: Veda, vydavatel'stvo SAV.

Midriak, R. (1983). Morphogenesis of high-mountain relief (Morphological study with focus on soil destruction in Western Carpathians) (in Slovak). Bratislava: Veda, vydavatelstvo SAV.

Nemčok, J. (1994). Geological bedrock (in Slovak). In I. Vološčuk (Ed.), Tatras National Park. Biosphere Reserve (pp. 14-24). Martin: GRADUS. 
Oksanen, J., Guillaume Blanchet, F., Friendly, M., Kindt, R., Legendre, P., McGlinn, D., Minchin, P.R., O'Hara, R.B., Simpson, G.L., Solymos, P., Stevens, M.H.H., Szoecs, E. \& Wagner H. (2017). Vegan: Community ecology package. R package version 2.4-4.

Olofsson, J., Kitti, H., Rautiainen, P., Stark, S. \& Oksanen L. (2001). Effects of summer grazing by reindeer on composition of vegetation, productivity and nitrogen cycling. Ecography, 24(1), 13-24. DOI: 10.1034/j.1600-0587.2001.240103.x.

Palaj, A. \& Kollár J. (2017). Contribution to the knowledge of the alpine vegetation of the Western Tatras. Phytopedon, 16(1), 9-13.

Pauli, H., Gottfried, M., Dullinger, S., Abdaladze, O., Akhalkatsi, M., Alonso, J.L.B., Coldea, G., Dick, J., Erschbamer, B., Calzado, F.R., Ghosn, D., Holten, J.I., Kanka, R., Kazakis, G., Kollár, J., Larsson, P., Moiseev, P., Moiseev, D., Molau, U., Mesa, J.M., Nagy, L., Pelino, G., Puşcaş, M., Rossi, G., Stanisci, A., Syverhuset, A.O., Theurillat, J.P., Tomaselli, M., Unterluggauer, P., Villar, L., Vittoz, P. \& Grabherr G. (2012). Recent plant diversity changes on Europe’s Montain Summits. Science, 336(6079), 353-355. DOI: 10.1126/science.1219033.

Pietorová, E. (1977). Alpine vegetation of the Račkova dolina valley (Western Tatras) (in Slovak). Diploma work (msc.), Faculty of Natural Sciences, Comenius University, Bratislava.

Plesník, P. (1974). Physical geography (in Slovak). In M. Konček (Ed.), Tatras climate (pp. 17-26). Bratislava: Veda, vydavatel'stvo SAV.

RStudio Team (2015). RStudio: Integrated development for R. Boston: RStudio, Inc. http://www.rstudio.com/.

Schei, F.H., Kapfer, J., Birks, H.J.B. \& Grytnes J.-A. (2015). Stability of alpine vegetation over 50 years in central Norway. Folia Geobot., 50, 39-48. DOI: 10.1007/s12224-015-9209-9.

Soukupová, L., Jeník, J. \& Frantík T. (2001). Edge effect of krummholz in Giant Mts. tundra, the Sudetes. Opera Corcontica, $38,77-87$.

Speed, J.D.M., Martinsen, V., Mysterud, A., Mulder, J., Holand, Ø. \& Austrheim G. (2014). Long-term increase in aboveground carbon stocks following exclusion of grazers and forest establishment in an alpine ecosystem. Ecosystems, 17, 1138-1150. DOI: 10.1007/s10021-014-9784-2.

Šály, R. (1964). The soils of Račkova and Jamnícka dolina valleys (in Slovak). Report. Tatranská Lomnica: TANAP administration.

Šibík, J., Kliment, J., Jarolímek, I. \& Dúbravcová Z. (2007). Loiseleurio-Vaccinieta. In J. Kliment \& M. Valachovič (Eds.), Plant communities of Slovakia. 4. Alpine vegetation (pp. 283-317). Bratislava: Veda, vydavatel'stvo SAV.

Šibík, J. (2012). Slovak vegetation database. In J. Dengler, J. Oldeland, F. Jansen, M. Chytrý, J. Ewald, M. Finckh, F. Glöckler, G. Lopez-Gonzalez, R.K. Peet \& J.H.J. Schaminée (Eds.), Vegetation databases for the 21st century. Biodiversity \& Ecology, 4(1), 429-429. DOI: 10.7809/b-e.00216.

Šmarda, J. (1963). Secondary plant communities in the High Tatras National Park (in Slovak). Bratislava: Šport.

Tichý, L. (2002). JUICE, software for vegetation classification. J. Veg. Sci., 13, 451-453. DOI: 10.1111/j.1654-1103.2002. tb02069.x.

Tilman, D. (1988). Plant strategies and the dynamics and structure of plant communities. Princeton: Princeton University Press.

Turečková, J. (1974). Subalpine and alpine vegetation of Jamnícka dolina valley (Western Tatras) (in Slovak). Diploma work (msc.), Faculty of Natural Sciences, Comenius University, Bratislava.

Vanneste, T., Michelsen, O., Graae, B.J., Kyrkjeeide, M.O., Holien, H., Hassel, K., Lindmo, S., Kapás, R.E. \& De Frenne P. (2017). Impact of climate change on alpine vegetation of mountain summits in Norway. Ecol. Res., 32, 579-593. DOI: $10.1007 /$ s11284-017-1472-1.

Virtanen, R. (2000). Effects of grazing on above-ground biomass on a mountain snowbed, NW Finland. Oikos, 90, 295300. DOI: 10.1034/j.1600-0706.2000.900209.x.

Walker, M.D., Wahren, C.H., Hollister, R.D., Henry, G.H.R., Ahlquist, L.E., Alatalo J.M., Bret-Harte, M.S., Calef, M.P., Callaghan, T.V., Carroll, A.B., Epstein, H.E., Jónsdóttir, I.S., Klein, J.A., Magnússon, B., Molau, U., Oberbauer, S.F., Rewa, S.P., Robinson, C.H., Shaver, G.R., Suding, K.N., Thompson, C.C., Tolvanen, A., Totland, Ø., Turner, P.L., Tweedie, C.E., Webber, P.J. \& Wookey P.A. (2006). Plant community response to experimental warming across the tundra biome. Proc. Natl. Acad. Sci. USA, 103(5), 1342-1346. DOI: 10.1073/pnas.0503198103.

Witkowska-Žuk, L. \& Ciurzycki W. (2000). Sukcesja roślinności na terenach wyłączonych z wypasu owiec w Tatrzańskim Parku Narodowym w latach 1965-1994 (in Polish). Ochrona Przyrody, 57, 19-40.

Zeidler, M., Banaš, M., Duchoslav, M. \& Lešková M. (2010). The impact of dwarf pine plantation on alpine plant communities in the Hrubý Jeseník Mts (in Czech). Príroda, 27, 38-52. 